\title{
PERAN DEWAN RISET DAERAH DALAM PERENCANAAN PEMBANGUNAN DI KABUPATEN SLEMAN
}

\author{
Muhammad Baiquni \\ Fakultas Geografi, Universitas Gadjah Mada \\ Jalan Kaliurang, Sekip Utara, Bulaksumur Sinduadi Sleman \\ Kabupaten Sleman, 55281, Yogyakarta, Indonesia
}

\begin{abstract}
Abstrak
Penelitian ini bertujuan mengkaji peran Dewan Riset Daerah (DRD) dalam perencanaan pembangunan daerah di Kabupaten Sleman dan bagaimana agenda riset terkait dengan implementasi Tujuan Pembangunan Berkelanjutan (TPB). Makna penting dari penelitian ini adalah mengkaji inovasi dan kreativitas pemimpin daerah dalam mengaitkan pelaksanaan pembangunan daerah. Metode penelitian ini adalah kajian pustaka, wawancara mendalam dan sarasehan. Hasil penelitian menunjukkan bahwa peran DRD Sleman telah berlangsung lama hampir 20 tahun dan telah memberikan masukan penting bagi pimpinan daerah dan jajaran perencana di Bappeda untuk menyerap hasil riset bagi kebijakan pembangunan daerah. Peranserta perguruan tinggi di Kabupaten Sleman juga menunjukkan antusias yang tinggi ditandai dengan minat keikutsertaan hibah riset dan pengabdian masyarakat bagi pembangunan Kabupaten Sleman.
\end{abstract}

Kata kunci: peran riset, tujuan pembangunan berkelanjutan, kepemimpinan

\begin{abstract}
This research objective is to study the role of Local Resarch Council in development planning in Sleman Regency and also how Sustainable Development Goals integrated in the development program. Strategic meaning of this research also exploring the role of the leader in implementing development progam. The research metodes employed are literature study, indepth interview and focus group discussion. The research results show that Local Research Council established almost 20 years ago which has contributed to strategic inputs to the leaders and also to Bappeda. The involvement of universities and research institutes have improved the development plans and implementations.
\end{abstract}

Key words: role of the research, sustainable development goals, leadership

\section{PENDAHULUAN}

Kabupaten Sleman terdapat kampus perguruan tinggi dengan jumlah mahasiswa yang banyak. Jumlah dan kualitas aparatur pemerintahan daerah juga relatif tinggi ditunjukkan dengan level pendidikannya. Keberadaan Dewan Riset Daerah dalam menunjang inovasi pembangunan perlu dikaji dan dicermati seberapa penting peran riset dalam pembangunan daerah, terutama terkait dengan perencanaan pembangunan daerah. Banyak sarjana bekerja di berbagai lini birokrasi dan bahkan banyak yang memiliki gelar master sebagai tanda bahwa kabupaten ini potensial untuk menjadi Smart Region yang dapat mewujudkan Tujuan Pembangunan Berkelanjutan di Kabupaten Sleman.

Penelitian ini dilaksanakan di Kabupaten Sleman yang dipilih, karena banyak prestasi yang diraih serta menjadi tempat ajang belajar dari pemerintah daerah lainnya. Disamping itu pemimpinnya bersemangat dalam mengembangkan kedaulatan dan kemandirian pembangunan daerahnya. Hingga saat ini telah dilakukan sejumlah

$$
\text { PeranDewan | } 1
$$


terobosan pembangunan inovasi produkproduk pertanian pangan, pelayanan kesehatan maupun strategi branding dan pemasaran produk produk sehingga perlu dan menarik untuk dikaji. Inovasi pembangunan ini memiliki dampak bagi peningkatan kapasitas masyarakat dan kesejahteraan masyarakat.

Pemerintah Kabupaten Sleman berkomitmen terhadap pembangunan yang berorientasi pada kepentingan, kesejahteraan, dan kemandirian masyarakat. Hal ini tertuang dalam visi "Terwujudnya masyarakat Sleman yang lebih Sejahtera, Mandiri, Berbudaya dan Terintegrasikannya sistem e-government menuju smart regency (kabupaten cerdas) pada tahun 2021". Adapun misi Kabupaten Sleman sebagai berikut:

1. Meningkatkan tata kelola pemerintahan yang baik melalui peningkatan kualitas birokrasi yang responsif dan penerapan e-govt yang terintegrasi dalam memberikan pelayanan bagi masyarakat.

2. Meningkatkan pelayanan pendidikan dan kesehatan yang berkualitas dan menjangkau bagi semua lapisan masyarakat.

3. Meningkatkan penguatan sistem ekonomi kerakyatan, aksesibilitas dan kemampuan ekonomi rakyat, serta penanggulangan kemiskinan.

4. Memantapkan dan meningkatkan kualitas pengelolaan sumberdaya alam, penataan ruang, lingkungan hidup dan kenyamanan.

5. Meningkatkan kualitas budaya masyarakat dan kesetaraan gender yang proporsion

Rumusan visi dan misi $e$ Govermnent secara eksplisit dinyatakan dengan jelas. Hal ini terkait dengan kekuatan SDM birokrat dan instrastruktur informasi yang telah tersedia dengan handal, didukung lembaga pendidikan tinggi dan lembaga riset yang banyak terdapat di Kabupaten Sleman.

\section{METODE PENELITIAN}

Penelitian ini merupakan penelitian kualitatif yang dilakukan dengan wawancara mendalam (indepth interview) dengan para narasumber kunci yaitu anggota Dewan Riset Daerah periode sebelum tahun 2017 dan satu narasumber dari DRD Kabupaten Magelang dan satu tenaga ahli DRD Kabupaten Kebumen. Tahapan penelitian dan metodenya dilakukan dengan serangkaian kegiatan:

1. Studi literatur dari buku referensi, dokumen laporan Agenda Riset Daerah dan RPJMD. Studi literatur berguna untuk memetakan data dan informasi mengenai agenda riset dan rencana pembangunan daerah, sehingga dapat dipilah dan dipilih untuk lebih di dalami melalui metode selanjutnya.

2. Wawancara mendalam dengan pimpinan daerah dan tokoh masyarakat dalam hal ini anggota Dewan Riset Daerah (DRD), kemudian dilakukan triangulasi untuk cek recheck data. Wawancara mendalam merupakan bentuk penjaringan data primer guna menemukan data dan informasi yang lebih mendetail dan rinci untuk menjelaskan fenomena yang diteliti.

3. Analisis data dan penulisan laporan. Analisis data terutama analisis kualitatif disarikan dari informan kunci, unit-unit informasi dikelompokkan dalam tema-tema tertentu, sehingga dapat dianalisis dan ditulis kajian fenomena yang diteliti.

\section{HASIL DAN PEMBAHASAN}

Tantangan Pembangunan Kabupaten Sleman

Dalam dokumen Agenda Riset Daerah (2016-2021), disebutkan permasalahan yang dihadapi Kabupaten Sleman, utamanya berkenaan dengan pemerintahan, pembangunan wilayah, infrastruktur dan kesejahteraan rakyat. Permasalahan terkait pemerintahan meliputi: (1) potensi keuangan daerah 
belum tergali secara optimal; (2) kompetensi sebagian pegawai belum sesuai dengan kebutuhan riil; (3) penegakan hukum belum efektif; (4) produk hukum daerah masih banyak yang tidak sesuai dengan perkembangan keadaan; (5) SKPD belum semua memiliki Standar Pelayanan Minimal dan Prosedur Standar Operasional; (6) pelayanan perizinan belum optimal; (7) pelimpahan kewenangan kepada kecamatan belum optimal; (8) hasil-hasil pengawasan belum sepenuhnya menjadi input perencanaan pembangunan (DRD Kabupaten Sleman, 2016).

Permasalahan bidang infrastruktur utamanya terkait dengan permasalahan kapasitas dan utilisasi infastruktur. Dalam konteks infrastruktur transportasi, Kabupaten Sleman dilalui oleh jalur transportasi yaitu jalan dan kereta api yang menghubungkan Provinsi Jawa Tengah, Jawa Barat dan Jawa Timur. Dalam konteks kawasan, Kabupaten Sleman memiliki jaringan jalan yang baik, meskipun secara kapasitas memperlihatkan penurunan kinerja, utamanya di wilayah- wilayah perkotaan yang ditandai dengan terjadinya kemacetan di jalan-jalan utama terutama yang menghubungkan antara Kabupaten Sleman dan wilayah Kota Yogyakarta. Hal ini diperparah dengan kurang layaknya angkutan umum yang ada saat ini tersedia untuk melayani desa dan kota di Kabupaten. Peran anggota DRD yang memiliki latar elakang transportasi dan logistik berujar sebagai berikut:

"Sebagai peneliti Pustral dan menjadi anggota DRD lebih fokus pada infrastrktur. Posisi wilayah Sleman sangat strategis terkait dengan konstelasi sistem transportasi di DIY dan kota lainnya. Sleman memiliki akses airport, stasiun, dan jalan darat. Infrastruktur baru sedang dibangun airport Kulonprogo dan jalur jalan toll melalui Sleman" (Iwan, peneliti Pustral UGM)

Permasalahan yang terkait dengan kesejahteraan rakyat antara lain: (1) masih tingginya angka kemiskinan, mencapai $40.711 \mathrm{KK}$, atau setara dengan 11,36\% jumlah penduduk; (2) angka pengangguran tergolong tinggi, yakni sebesar 25.943 orang atau sebesar 6,17\%; (3) ketimpangan pendapatan yang ditunjukkan dengan Indeks Gini sebesar 0,$45 ; \quad$ (4) masih terdapat backlog (kekurangan) rumah sekitar 17.466 rumah; (5) masih adanya praktik-praktik intoleran; (6) menurunnya kohesivitas sosial; (7) meningkatnya rasa individual dan egosentrisme serta menurunnya semangat kegotongroyongan (DRD Kabupaten Sleman, 2016).

Berbagai permasalahan tersebut perlu perhatian bagi semua stakeholder yang berkepentingan terhadap keberlanjutan pembangunan Kabupaten Sleman yang berupaya mewujudkan masyarakat Sleman menuju lebih sejahtera, mandiri, berbudaya dan terintegrasikannya sistem e-government menuju smart regency pada tahun 2021. Dalam hal ini, kontribusi dalam penyelesaian masalah sekaligus pencapaian visi Kabupaten Sleman perlu dilakukan dengan melalui penerapan, pengembangan dan inovasi ilmu pengetahuan dan teknologi.

Penerapan, pengembangan dan inovasi ilmu pengetahuan, baik yang dilakukan oleh Pemerintah Kabupaten Sleman, perguruan tinggi maupun masyarakat luas perlu mendasarkan pada informasi dan kebutuhan riset yang betulbetul dibutuhkan oleh Kabupaten Sleman. Berkenaan dengan hal tersebut, maka penyusunan Agenda Riset Daerah Kabupaten Sleman Tahun 2016 - 2021 menjadi hal yang penting untuk dilakukan.

\section{Peran Riset Dalam Pembangunan Daerah} Pentingnya riset dalam pembangunan daerah memerlukan komitmen kepala daerah, kemampuan para peneliti dan penerimaan birokrat, serta sarana dan prasarana pendukungnya. Hal ini diakui oleh Sutrisno yang pernah menjadi sekretaris 
daerah yang melayani tiga bupati di Kabupaten Sleman, sebagai berikut:

"Saya berpandangan teorinya Stephen Robbins dan Timothy Judge dalam bukunya Organizational Behavior relevan untuk mengembangkan kepemimpinan dan kelembagaan "Performence is the function of motivation, ability and environment". Pada waktu saya di Bappeda, saya mendorong staf sekolah ke luar negeri agar kelak menjadi lebih berkualitas. Motivasi sangat penting berangkat dari individu, ability dimampukan melalui pendidikan dan pelatihan, sedangkan environment termasuk fasilitas dan instruktur dukungan kerja yang dapat mendorong peningkatan kinerja kepemimpinan dan kelembagaan" (Sutrisno ketua DRD Sleman).

Peran penelitian sangat penting dalam pembangunan daerah. Beruntung Sleman terdapat perguruan tinggi dan lembaga riset termasuk LSM yang bisa menjadi sumber pemikiran kritis dan inspirasi bagi kebijakan dan program pembangunan.

Pelaksanaan pembangunan daerah memerlukan semangat yang juga didasarkan pada hasil riset agar tepat guna kebijakan dan dapat berkelanjutan.

"Bekerja juga harus memiliki landasan teori dan teori harus dikerjakan, sehingga menemukan pengalaman yang bisa menjadi teori baru" (Sutrisno ketua DRD Sleman).

Birokrasi memerlukan penyegaran salah satunya melalui hasil riset yang dapat diserap bagi inovasi pembangunan daerah. Sebagaimana yang dinyatakan dosen program studi Pembangunan Wilayah UGM yaitu:

"Riset Unggulan Daerah (RUD) didisain untuk memperoleh pengetahuan praktis yang digali dari daerah sendiri dalam rangka memfasilitasi hasil riset adalah era baru bagi daerah, karena ini sangat sejalan dengan semangat good governance" (Rijanta, peneliti PSPPR UGM).

Aparat Sipil Negara (ASN) sebagai pelaksana birokrasi memerlukan peningkatan kapasitas secara bertahap dan berjenjang sehingga dari staf paling muda menjadi matang memimpin diperlukan waktu 15 hingga 20 tahun. Pemerintah pusat telah memiliki program pelatihan dan bahkan pendidikan pascasarjana di dalam maupun di luar negeri. Pada periode tahun 2000an banyak staf muda dari Kabupaten Sleman mengikuti program pendidikan bagi birokrat muda untuk belajar di luar negeri baik program short course maupun program master ke Amerika, Inggris, Belanda, Jepang, Australia. Ada sekitar 20an staf pemerintah daerah yang mendapat kesempatan ini. Dari pengalaman selama ini, terbukti bahwa setelah 15 tahun baru panen para pejabat profesional yang sekarang menduduki kepala dinas adalah kebanyakan pernah belajar di luar negeri.

Kualitas SDM ini sangat membantu tugas kepala daerah dalam mengembangkan pelayanan prima bagi masyarakat. Para ASN yang memiliki pengalaman pendidikan dan riset di berbagai daerah dan luar negeri dapat menyerap hasil-hasil riset yang dilakukan perguruan tinggi dan lembaga riset, sehingga menjadi masukan bagi kebijakan dan program pembangunan daerah. Semakin banyak ASN yang pernah mengenyam pendidikan di luar negeri dapat mengemban jabatan strategis, semakin berkembang inovasi pembangunan yang didasarkan atas riset dan masukan dari para ahli dari dalam maupun dari luar lingkungan pemerintah daerah.

Peran riset dalam pembangunan daerah, telah dilakukan oleh DRD dengan menyusun Agenda Riset Daerah yang pelaksanaannya dilakukan oleh segenap pelaku dan pemangku kepentingan pembangunan daerah. Terkait peran anggota DRD juga telah melaksanakan 
fasilitasi, masukan dan pemantauan memalui berbagai kesempatan.

"Sesuai bidang keahlian, anggota DRD berperan dalam berbagai kegiatan antara lain menjadi juri berbagai lomba disain, penelitian, menyelenggarakan sarasehan ekonomi kreatif, dan yang terakhir ini menjaring proposal riset dan mengawal riset yang dilakukan perguruan tinggi" (Sri Nur Hidayah, kepala sub bidang penelitian dan pengembangan Bappeda).

\section{Keberadaan DRD dan Hubungannya Dengan Bappeda}

Keberadaan Dewan Riset Daerah

Kabupaten Sleman telah lama terbentuk dan bahkan termasuk perintis awal DRD di Indonesia. Kemunculannya tak lepas dari peran dan dukungan Dewan Riset Nasional yang mendorong dan mengembangkan DRD untuk memberi masukan bagi pembangunan daerah. Para anggota DRD tidak hanya mereka yang berasal dari kampus dan birokrat, tetapi juga ada tokoh masyarakat seperti petani andalan Gunung Sutopo yang terlibat sejak awal merintis kelembagaan ini:

"Pada suatu malam di tahun 2010 diundang bertemu di rumah bupati bersama menemui tamu DRN Jakarta. Dibicarakan mengenai pentingnya membentuk DRD dan baru pertama di Sleman ini dengan bimbingan DRN dapat dibentuk" (Gunung Sutopo, petani dan anggota DRD).

Pelibatan staf muda di birokrasi juga menjadi perintis awal pembentukan kelembagaan DRD yang semula ditempatkan di Sekretariat Daerah, kemudian sekarang ditempatkan di Bappeda. Pelibatan sejak awal dan terus berkembang bersama dengan karir, Sri Nur Hidayah mengawal perkembangan DRD sebagaimana ungkapan berikut ini:

"Pembentukan awal DRD 2010 sudah ditugaskan disini, awalnya DRD di Sekretariat Daerah kemudian dialihkan ke Bappeda. Awalnya penjaringan rapat dan audiensi memberi masukan ke bupati.
Kemudian menyusun Agenda Riset Daerah 2011-2015 sesuai RPJMD dan dilanjutkan yang kedua Agenda Riset Daerah 2016-2021" (Sri Nur Hidayah, kepala sub bidang penelitian dan pengembangan Bappeda).

Salah satu produk DRD Kabupaten Sleman adanya Agenda Riset Daerah yang Kabupaten Sleman 2016-2021, adapun tujuan yang tertulis dalam dokumen adalah

1. Menjawab permasalahan pembangunan melalui pengembangan ilmu pengetahuan dan teknologi;

2. Memberikan arah bagi kegiatan penelitian, pengembangan dan penerapan ilmu pengetahuan dan teknologi yang dilakukan oleh pemerintah, akademisi, lembaga penelitian dan masyarakat bagi Kabupaten Sleman.

Disadari bahwa pemanfaatan ilmu pengetahuan dan teknologi dalam kegiatan riset merupakan bagian yang tidak terpisahkan dengan penyelenggaraan pembangunan daerah. Kemajuan dan tingkat penguasaan Iptek merupakan faktor penting bagi peningkatan kapasitas kapabilitas sumberdaya manusia dalam pembangunan di daerah agar segenap potensi dapat dikembangkan dengan nilai tambah yang meniningkat secara berkualitas dan berkelanjutan. Tingkat kemajuan dan penguasaan Iptek merupakan salah satu tolok ukur kemajuan daerah bersama dengan tolok ukur lain seperti pertumbuhan ekonomi, kualitas demokrasi, dan supremasi hukum.

Tujuan dari Pembangunan Berkelanjutan belum dijadikan pijakan dalam Agenda Riset Daerah 2016-2021 ini. Hal ini dapat dipahami karena saat persiapan penyusunan dokumen belum keluar panduan Tujuan Pembangunan Berkelanjutan atau dikenal dengan Sustainable Development Goals (SDGs) yang 
baru diluncurkan awal 2016. Dalam perkembangannya SDGs menjadi rujukan, terbukti setiap tahun ada laporan progres pembangunan daerah dengan mengacu pencapaian SDGs.

"Setiap tahun ada laporan pencapaian SDGs, bidang IV ada tugas pendataan dan pelaporan setiap tahun bahkan sejak MDGs". Ia melanjutkan pembicaraannya bahwa "DRD perlu membantu memberikan masukan dan pendampingan untuk pelaporan SDGs, perlu sistem informasi pencapaian setiap sektor agar juga pelaporan konsisten dan kontinyu sampai 2030" (Kunto Riyadi, kepala Bappeda Sleman).

Beragam Tujuan Pembangunan Berkelanjutan perlu diterjemahkan dalam kebijakan dan program yang dilaksanakan oleh OPD dan dikoordinasikan perencanaannya oleh Bappeda. Implementasi program yang terkait SDGs sebenarnya telah ada, hanya saja koordinasi, keterpaduan dan sinergi dilapangan perlu terus dikembangkan.

"Isu sustainability perlu menjadi perhatian, karena pentingnya infrastrukur terkait dengan energi terbarukan dan bagaimana pembangunan bisa berkelanjutan. Bergabung dengan DRD 2014, dengan membawa hasil riset dari kampus untuk dapat memberi kontribusi pada pembangunan daerah Kabupaten Sleman" (Iwan, peneliti Pustral UGM)

Tujuan dari Pembangunan Berkelanjutan yang merupakan tujuan jangka panjang 2016-2030 memerlukan sistem perencanaan, pelaksanaan, pengendalian, pemantauan dan penilaian yang menggunakan sistem informasi digital. Oleh karena itu diperlukan penerapan ICT dalam proses tata kelola berbagai sektor pembangunan menuju tujuan yang ingin dicapai. Kesadaran memanfaatkan ICT sebagai cara Smart Governance telah ada dikalangan praktisi dan birokrasi.

\begin{abstract}
"Tulisan Seabad Sleman dan Mewujudkan Sleman Smart Regency di media. Berkaitan dengan bidang pertanahan dan penataan ruang yang saya tekuni, maka beberapa aspek kebijakan perlu dicermati karena tak lepas dari tata kelola pertanahan dan tata ruang dalam mewujudkan Smart Regency". Dengan bersemangat, dosen Sekolah Tinggi Pertanahan yang alumni doktor Geografi UGM ini menyatakan lebih lanjut: "Oleh karena itu dalam agenda riset daerah yang utama perlu kebijakan pertanahan dan tata ruang sebagai basis dasar kebijakan lainnya. DRD memberikan input riset secara langsung bertemu dengan bupati, sehingga bisa menjadi kebijakan yang berbasis riset" (Sutaryono, anggota DRD).
\end{abstract}

Pengembangan riset daerah diperlukan untuk memperkuat landasan kebijakan yang terintegrasikan dengan Rencana Pembangunan Jangka Menengah Daerah (RPJMD). Dalam hal ini penyusunan Agenda Riset Daerah Kabupaten Sleman menjadi urgent, untuk dijadikan panduan bagi para peneliti, baik oleh Pemerintah Kabupaten Sleman sendiri, kalangan perguruan tinggi maupun masyarakat termasuk kalangan pengusaha. Hasil-hasil riset yang dilakukan dengan mendasarkan Agenda Riset Daerah ini diharapkan dapat berkontribusi positif dalam penyelesaian permasalahan pembangunan sekaligus menjadi bahan pertimbangan dalam pembangunan dan pengembangan Kabupaten Sleman pada berbagai sektor (Dewan Riset Daerah 2016).

Adapun bidang pembangunan ilmu pengetahuan dan teknologi pada Agenda Riset Daerah Kabupaten Sleman Tahun 2016 - 2021 ditetapkan sebagai berikut

1. Bidang Pemerintahan, Kelembagaan dan Aparatur;

2. Bidang Hukum dan Regulasi;

3. Bidang Perekonomian;

4. Bidang Kesejahteraan Rakyat; 
5. Bidang Infrastruktur, Lingkungan Hidup dan Tata Ruang.

Keberadaan DRD terkait dengan tugas Bappeda dirasakan penting untuk mendampingi pelaksanaan koordinasi perencanaan pembangunan daerah. Riset berbasis konteks lokal dan solusional sesuai dengan ekosistem dinamika pembangunan daerah amat penting agar kebijakan dan program pembangunan tepat guna.

"DRD berperan mendukung pemerintah daerah dalam hal ini Bappeda memfasilitasi kegiatan penelitian yang diorientasikan untuk mendukung pembuatan keputusan rasional yang berbasis pengetahuan setempat. Penyelesaian berbagai masalah dalam pembangunan akan lebih tepat jika didasarkan atas pengetahuan dengan konteks lokalitasnya yang valid dan dapat diandalkan" (Rijanta, peneliti PSPR UGM).

DRD bersama Bappeda menjalankan fungsi riset dalam hal ini DRD sebagai think tank kelompok pemikir yang perencanaan teknokratis disiapkan dan dilakukan Bappeda. Dalam melaksanakan riset melibatkan OPD teknis sebagai pengusul topik yang sekaligus akan memanfaatkan pengetahuan yang diperoleh untuk pelaksanaan pelayanan dan pembangunan daerah.

"Peran DRD juga memberikan masukan pada dokumen perencanaan, mulai dari konsultasi publik hingga penyusunan rencana program pembangunan daerah" (Sri Nur Hidayah, kepala sub bidang penelitian dan pengembangan Bappeda).

Hal ini juga dikuatkan dengan pendapat anggota DRD yang merupakan petani andalan dengan kebun buah dan agrowisata Sabila Farm. Dengan pengalaman lapangan yang panjang dan interaksi dengan berbagai pihak yang luas, Gunung Sutopo cukup lantang dalam menyuarakan pengalaman lapangan riset aksinya.

"DRD penting untuk memberi masukan pada bupati baik langsung maupun melalui Bappeda sebagai badan perencana yang menerjemahkan kebijakan pimpinan daerah" (Gunung Sutopo, petani dan anggota DRD).

Dengan demikian para anggota DRD ini menjadi think tank yang menjembatani antara pola pikir birokrasi dengan pola pikir riset baik dengan pendekatan riset aksi maupun riset akademisi. Sebuah kombinasi yang baik dan tepat untuk memperkaya kinerja perencanaan dan pelaksanaan pembangunan daerah.

\section{Agenda Riset Daerah dan RPJMD 2016-} 2021

Agenda Riset Daerah telah seiring dengan RPJMD 2016-2021, namun belum memuat secara eksplisit strategi bagaimana Tujuan Pembangunan Berkelanjutan 2016-2030 disinergikan.

"Riset smart governance saat ini sedang berlangsung. Dipetakan kesiapan dan kebutuhan penerapan ICT untuk mendukung good governance. Beberapa OPD sudah melaksanakan, tetapi yang lain belum. Hasil riset yang sekarang berjalan diharapkan akan menjadi pedoman dan rambu bagi daerah untuk implementasi smart city $\mathcal{E}$ region (Rijanta, peneliti PSPPR UGM).

Agenda Riset Daerah terkait dengan pengembangan Iptek di daerah guna menciptakan nilai tambah dari sumberdaya yang ada. Pengembangan Iptek diharapkan mendorong inovasi dan kreativitas daerah dalam mengelola pembangunan daerah. Hal ini diungkapkan bahwa tugas DRD terkait dengan:

"Membantu bupati dalam merumuskan arah dan prioritas utama pembangunan, Ipteks, memberikan pertimbangan kepada bupati dalam penyusunan kebijakan strategis pembangunan daerah Iptek, dan menyusun riset daerah" (Su 
Ritohardoyo ketua DRD Kabupaten Magelang)

Belajar dari pengalaman Kabupaten Magelang dan Kabupaten Kebumen yang telah menyelenggarakan sayembara riset, DRD Kabupaten Sleman pada tahun 2019 ini mulai membuka riset bagi para peneliti perguruan tinggi dan lembaga riset swasta untuk berpartisipasi. Topik penelitian yang ditawarkan mengenai pertanian berkelanjutan dan tata kelola kelembagaan pariwisata serta topik terkait. Para peneliti yang ikut sayembara riset saat ini mencapai 75 proposal dari perguruan tinggi negeri maupun swasta yang mayoritas berkedudukan di Sleman. Sayembara penelitian ini juga dibuka untuk proposal dari daerah lain, namun kenyataannya yang masuk banyak dari Sleman. Berbeda dengan di Magelang dan Kebumen, proposal yang masuk dan menang dari luar kabupaten tersenut.

"Riset ini didesain untuk dikompetisikan secara bebas bagi dosen dari berbagai perguruan tinggi di Indonesia, namun pemenangnya selalu dari perguruan tinggi besar yang kapasitas risetnya memang sudah lebih mapan. Selama 3 tahun saya menjadi tim ahli DRD Kabupaten Kebumen, hanya satu-dua topik saja yang pernah dimenangkan oleh lembaga riset atau perguruan tinggi setempat. Bagi pemerintah daerah ini satu keuntungan, karena akan dapat hasil riset yang baik dengan biaya yang relatif murah. Tetapi untuk pemberdayaan institusi riset lokal tampaknya belum cukup berhasil" (Rijanta, peneliti PSPPR UGM).

Integrasi dan sinergi Agenda Riset Daerah dalam memperkaya RPJMD Kabupaten Sleman 2016-2021 inginnya juga mengakomodasi pelaksanaan Tujuan Pembangunan Milenium. Hal ini dikemukakan oleh Kepala Bappeda Kabupaten Sleman sebagai berikut:

"Bila ada yang telah bikin secara pelaporan nasional SDGs secara nasional, dan kemudian disesuaikan dengan kondisi dan potensi daerah masing-masing" (Kunto Riyadi, kepala Bappeda Sleman).

Peran strategis DRD juga memberi masukan langsung kepada Bupati dan secara tak langsung melalui kelembagaan Bappeda yang nanti disampaikan kepada Bupati.

"Peran DRD memberi masukan ke Bupati dan secara kelembagaan disalurkan melalui Bappeda. Lebih luas lagi dari perencanaan, DRD punya peran untuk menyuarakan ke OPD dan bila riset hasilnya bagus untuk bisa dikembangkan secara luas bisa ditangkap oleh masingmasing institusi pelaksana sesuai dengan tugas dan fungsi pelaksanaan kegiatan pembangunan" Ia melanjutkan perbincangan dengan menyampaikan pernyataan bahwa"Hasil riset nanti bisa membantu menginspirasi dan mendampingi dalam perencanaan, pelaksanaan, monitoring dan evaluasi pembangunan sehingga akan lebih baik hasilnya" (Kunto Riyadi, kepala Bappeda Sleman).

Keragaman para anggota baik dalam bidang ilmu dan latar belakang pengalaman memberi warna tersendiri bagi dinamika DRD.

"DRD yang memiliki anggota para ahli dari berbagai bidang keilmuan dan keahlian, melalui riset berkontribusi agar Kabupaten Sleman menjadi Smart Regency" (Gunung Sutopo, petani dan anggota $D R D)$.

Kelancaran pelaksanaan fungsi dan peran DRD di fasilitasi Bappeda, memberi ruang dan sekretariat pelaksana DRD di Kantor Bappeda termasuk disediakan staf yang mengurus administrasi DRD. Pengalaman berharga bagi staf muda yang baru dapat berinteraksi langsung dengan para peneliti senior di DRD, sebagaimana yang disampaikan Danik sebagai berikut:

"Selesai sekolah 2017 diajak membantu memfasilitasi kelancaran di DRD. Memperlancar sekretariat sebagai 
fungsional perencana dan belajar dari para tim ahli. Kami diikutkan untuk membantu penyusunan EKPD setiap tahun dan penyusunan rencana RPJMD" (Danik Kusumaningbudi, staf pelaksana sekretariat DRD)

Dengan demikian agenda riset yang disusun oleh anggota yang beragam keilmuan dan pengalaman ini dapat diintegrasikan dan disinergikan dengan rencana pembangunan jangka menengah.

\section{Inovasi Kepemimpinan Dan Solusi Pembangunan Daerah}

Inovasi berangkat dari kualitas SDM dan lingkungan kerja yang mendukung. Pemimpinan selalu memupuk motivasi pada para pengikutnya dalam hal ini staf birokrasi yang melaksanakan pelayanan publik dan pembangunan daerah. Spirit dan semangat kerja harus ditumbuhkan, ditunjang dengan peningkatan kapasitas melalui pendidikan dan pelatihan serta didudung dengan atmosfir kerja termasuk sarana dan prasarana pendukung, sehingga kinerja dapat optimal. Dalam dinamika persaingan pembangunan daerah, diperlukan pemimpin yang inovatif membawa aparat bekerja dengan hati dan sepenuh hati serta secara hati-hati.

Pengalaman birokrat senior yang selalu membuat beragam istilah yang mengena dalam kultur budaya birokrasi di Kabupaten Sleman, Sutrisno mengungkapkan berulang-ulang sehingga merasuk dalam kesadaran stafnya. Pitutur atau ujaran penuh hikmah yang sering diungkapkannya antara lain:

"Kalau bisa hebat, baik saja tidak lah cukup" merupakan kata motivasi bagi yang muda terus saya hembuskan. "Kita sujud diatas sajadah, mbok hidup kita juga menjadi jalan lurus dalam kehidupan nyata" (Sutrisno, ketua DRD Sleman).

Perlu dipahami bahwa untuk menyiapkan SDM dan sistem yang sesuai dengan perkembangan dan tantangan jaman, diperlukan serangkaian pelatihan dan praktek yang panjang. Pengalaman itu merupakan akumulasi gagasan, rencana, pelaksanaan, pemantauan dan pemenuhan hasil baik itu luarannya keberhasilan maupun kegagalan. Pengalaman itu menunjukkan kematangan seseorang dalam memimpin mampu mengetahui jalannya, menjalaninya dan memberikan petunjuk jalan bagi para pengikutnya. Pengalaman kepemimpinan juga ditunjang dengan pendidikan dan pemberian kesempatan, sebagaimana yang dialami oleh Sutrisno yang menyatakan:

"Saya disekolahkan Overseas Training Office (OTO) Bappenas sekitar tahun 1989an mendapat kesempatan sekolah di luar negeri yaitu di Kanada. Sebenarnya setelah lulus ditahun 1980, saya sudah berkesempatan untuk belajar ToT khususnya management and planning dan menjadi trainer keliling Indonesia. Metode Logical Framework, GOPP/ZOPP, GPOI untuk mengembangkan tata kelola pembangunan daerah. Local Government Training merupakan program pemerintah pusat untuk memajukan daerah seiring dengan keinginan demokratisasi dan otonomi daerah. Pemerintah menyiapkan program ini dengan prediksi nanti pada masanya, pembangunan daerah sangat membutuhkan tenaga profesional berkualitas dan berwawasan luas (Sutrisno, ketua DRD Sleman).

Secara teori ada 5 kunci sukses organisasi, yaitu: kultur, kualitas anggota, cara berkomunikasi, sumberdaya, dan kepemimpinan. Diantara lima kunci sukses, kepemimpinan memiliki peran yang sentral dalam berorganisasi, termasuk organisasi birokrasi pemerintah daerah. Pemimpin menjadi penting karena ia memiliki kewenangan untuk menentukan orientasi dan arah pembangunan yang dirumuskan dalam visi dan misi pembangunan daerah. Melalui visi dan misi pemimpin kebijakan pembangunan diarahkan dan program pembangunan diterjemahkan kedalam kerja pelaksanaan pembangunan. 
Kapasitas dan kompetensi serta karakter kepemimpinan akan menentukan keberhasilan organisasi. Kultur birokrasi juga terbentuk dan dibentuk oleh pola kepemimpinan yang diterapkan, demikian pula kualitas aparat, cara komunikasi, ketersediaan sumberdaya akan menentukan efektifitas perwujudan visi dan misi menjadi implementasi pembangunan daerah. Secara struktural, dijelaskan oleh Sutrisno mantan Sekretaris Daerah dan Ketua Bappeda sebagai berikut:

"Bappeda menjadi kunci bagi penterjemahan arah kebijakan bupati dapat diturunkan menjadi program teknokratis birokrasi, sangat didengar oleh bupati. Dibawah bupati ada sekretaris daerah, yang memungkinkan dikoordinasikan semua hal terkait kebijakan. Selanjutnya dalam hal perencanaan ditangani Bappeda dan dipakai oleh pimpinan" (Sutrisno, ketua DRD Sleman).

Setiap pemimpin memiliki karakter, pola kerja, dinamika tantangan dan trend dalam pelaksanaan pembangunan daerah. Maing-masing memiliki masanya, ada tantangan dan persoalan yang harus dijawab dan keberhasilan yang diwujudkan. Berdasarkan pengalaman mendampingi para Bupati, Sutrisno mengamati kepemimpinan tiga bupati di Kabupaten Sleman sebagai berikut:

"Sebagai Sekretaris Daerah, saya mengamati setiap bupati memiliki ciri khas kepemimpinan berdasarkan karakter dan latar belakang karirnya. Ada tiga bupati dimana saya menjabat sebagai sekretaris daerah 1999-2011. Pertama bupati Arifin Ilyas sangat taat dengan birokrasi, karena latar belakang birokrasi yang kuat sehingga wajar kalau beliau memimpin dengan gaya birokrat. Kemudian kedua adalah Ibnu Subiyanto pemimpin yang percaya diri dan maju pesat dengan penuh ide besar sebagai pengagum Bung Karno. Dengan latar belakang perguruan tinggi, ia banyak gagasan yang ingin dikembangkan dengan jangka panjang dan berskala besar. Bupati Sri Purnomo dengan latar belakang guru nampak lebih berhati-hati dalam memimpin dalam dinamika pembangunan yang cepat. Pencapaiannya ternyata banyak dengan tim profesional birokrat yang pernah belajar di luar negeri tentang pembangunan daerah" (Sutrisno, ketua DRD Sleman).

Pada kepemimpinan Arifin Ilyas, mengawali era otonomi banyak rintisan birokrasi dasar dan peningkatan kualitas SDM staf birokrasi disekolahkan dengan beasiswa pusat ke luar negeri. Berikutnya bupati Ibnu Subiyanto misalnya, ada terobosan besar berkaitan dengan promosi pariwisata Sleman ke tingkat international tourism expo di Berlin selama 6 tahun berturut-turut selalu ikut dalam skema Java Pavilliun bekerjasama dengan industri pariwisata. Kemudian dikembangkan pula promosi pariwisata dengan mengajak 15 kabupaten kota dalam skema Java Promo. Saat ini bupati Sri Purnomo lebih diuntungkan dengan para birokrat profesional yang matang setelah lama sebelumnya disemaikan dan ditanam oleh para bupati terdahulu. Dengan demikian sebenarnya ada keberlanjutan estafet kepemimpinan, yang setiap pemimpin mengembangkan inovasinya bagi generasi berikutnya. Meskipun karakter person pemimpin beragam, namun bila sistem birokrasi mantab dengan kualitas aparat yang baik, akan menghasilkan kinerja yang baik pula.

\section{KESIMPULAN}

1. Riset penting bagi pembangunan daerah karena dapat menjadi landasan kebijakan dan penetapan strategi program yang sesuai dengan situasi dan kondisi daerah. Penerapan, pengembangan dan inovasi ilmu pengetahuan, baik yang dilakukan oleh Pemerintah Kabupaten Sleman, perguruan tinggi maupun masyarakat luas mendasarkan pada kebutuhan riset 
yang dibutuhkan oleh Kabupaten Sleman. Berkenaan dengan hal tersebut, maka Agenda Riset Daerah Kabupaten Sleman Tahun 2016-2021 menjadi hal yang penting untuk dilakukan.

2. Dewan Riset Daerah (DRD) memiliki hubungan yang baik dengan Badan Perencanaan Pembangunan Daerah (Bappeda) di Kabupaten Sleman, terbukti dengan keaktifan kegiatan melalui rapat dan koordinasi yang dilakukan. Para anggota DRD ini menjadi think tank yang menjembatani antara pola pikir birokrasi dengan pola pikir riset baik dengan pendekatan riset aksi maupun riset akademisi. Sebuah kombinasi yang baik dan tepat untuk memperkaya kinerja perencanaan dan pelaksanaan pembangunan daerah.

3. Agenda Riset Daerah (ARD) 2016-2021 dalam mengawal Rencana Pembangunan Menengah Daerah (RPJMD) belum secara tersurat mengacu pada Tujuan Pembangunan Berkelanjutan. Dalam pelaksanaan sejak 2016 setelah Tujuan Pembangunan Berkelanjutan diumumkan, maka Bappeda melaksanakan laporan tahunan yang mengacu pada SDGs.

4. Terdapat keberlanjutan estafet kepemimpinan di Kabupaten Sleman, yang dapat dilacak dari karya setiap pemimpin mengembangkan inovasinya bagi generasi berikutnya. Meskipun karakter person pemimpin beragam, namun bila sistem birokrasi mantab dengan kualitas aparat yang baik, akan menghasilkan kinerja yang baik pula. Solusi untuk mengatasi keterbatasan dan kendala yang dihadapi dapat dilakukan dengan kepemimpinan kolektif, komunikasi yang tepat guna, staf pelaksana yang berkualitas dan profesional, program pembangunan berbasis riset, serta sumberdaya yang mencukupi.

\section{UCAPAN TERIMA KASIH}

Dekan Fakultas Geografi UGM yang telah mendanai kegiatan peelitian ini, anggota DRD Kabupaten Sleman, ketua DRD Kabupaten Magelang dan tenaga ahli DRD Kabupaten Kebumen yang berkenan menjadi narasumber penelitian ini.

\section{DAFTAR PUSTAKA}

Baiquni, M. (2009). 3.4. Social Affairs: Gotong-Royong as Local Wisdom.

Baiquni, M. (2002). Susilawardani, Pembangunan yang tidak Berkelanjutan Refleksi Kritis Pembangunan Indonesia. Trans Media Global Wacana, Yogyakarta.

Baiquni, M (2014). Kepemimpinan Berkarakter Pancasila. Makalah disampaikan pada kuliah umum di BATAN Yogyakarta.

Bintarto. (1983). Gotongroyong Sebagai Suatu Karakter Bangsa Indonesia. Yogyakarta

Dewan Riset Daerah. (2016). Agenda Riset Daerah 2016-2021. Keputusan Bupati Sleman no 74.1/Kep.KDH/A/2016. Dewan Riset Daerah. Sleman.

Dewan Riset Nasional. (2016). Meningkatkan Peran Riset dan Inovasi Untuk Pembangunan Daya Saing Daerah. Seminar Nasional. Jakarta. www.drn.go.id

Ul Haq, M. (1983). Tirai Kemiskinan: tantangan-tantangan untuk Dunia ketiga. Terj. Masri Maris. Yogyakarta: Yayasan Obor Indonesia.

Hindle, T. (2008). Guide to management ideas and gurus (Vol. 42). John Wiley \& Sons.

Mattone, J. (2013). Intelligent Leadership: What You Need to Know to Unlock Your Full Potential. Amacom Books.

Mc Kinley. (2011). Local Government and Community Governance. Australian Center of Excellent for Local Governance. McKinley Douglas Ltd.

Nussbaum, B. (2013). Creative intelligence: Harnessing the power to create, connect, and inspire. Harper Collins.

David, O., \& Ted, G. (1992). Reinventing Government: how the entrepreneurial spirit is transforming the public sector.

Zuhal, K. (2010). Innovation (Platform Kekuatan Daya Saing). Jakarta, PT Gramedia Pustaka Utama. 